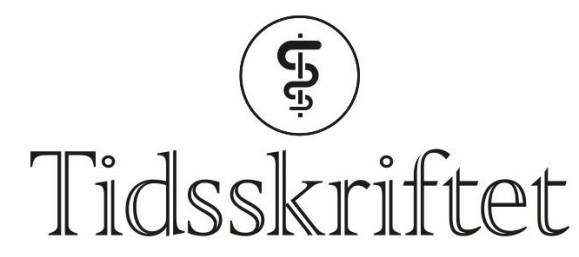

DEN NORSKE LEGEFORENING

\title{
VAP viser vei
}

ANMELDELSER

KRISTIN LIE ROMM

Spesialist i psykiatri, Oslo universitetssykehus

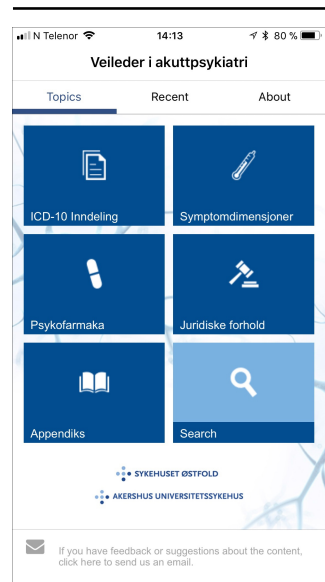

Veileder i akuttpsykiatri (VAP)

Sykehuset Østfold og Akershus universitetssykehus. Mobilapplikasjon. Oslo:

Sykehuspartner, 2017. Gratis til alle plattformer

Veileder i akuttpsykiatri (VAP) er en mobilapplikasjon (app) utviklet av og for leger.

Målgruppen er leger i spesialisering i vaktsituasjoner i akuttpsykiatrien. Dette er ofte leger med mindre erfaring, og lett tilgjengelig informasjon er derfor en god idé. VAP krever ingen innlogging og er gratis - dette er et pluss.

Når du åpner Veileder i akuttpsykiatri, får du tilgang til informasjon delt i seks hovedtemaer: ICD-1o-inndeling, Symptomdimensjoner, Psykofarmaka, Juridiske forhold, Appendiks og Søkefunksjon.

ICD-10-inndelingen bringer deg til ulike tilstandsbilder, men forholder seg ikke til kodeverket ICD-1o og er lite utfyllende. Kikker man på underkategoriene, er det uklart hva som er bakgrunnen for utvalget. Her kunne man kanskje vært litt mer fokusert i forhold til målgruppens behov (vakt).

Tilstandene inndeles etter definisjon, årsaker/risikofaktorer, symptomer/tegn, systematisk tilnærming, differensialdiagnoser og akutt behandling/tiltak. Beskrivelsene er kortfattede, men gir en ryddig beskrivelse av viktige momenter til vurdering. Jeg savner imidlertid klarere råd om praktiske tiltak og prosedyrer. Det hadde vært fint med klare retningslinjer for hvilke forhold som er akutte, og hvilke som kan vente.

Kategorien Symptomdimensjoner er uklar for meg. Hva menes med en symptomdimensjon? 
Det er ikke opplagt at kriser, selvskading, suicidalitet, søvnproblemer og uro/aggressivitet vil ligge bak dette. Når det er sagt, er disse punktene viktige for vaktleger, og de bør ha en sentral plass i applikasjonen.

Temaet Psykofarmaka er viktig, men utvalget som presenteres, er begrenset. Jeg kunne tenke meg en oversikt over de vanligste medikamentene og vanlige startdoser/akuttdoseringer, selv om dette finnes i Felleskatalog-appen. Det understrekes at man skal dokumentere medisinetterlevelse. Hva med pasientens tidligere erfaringer med medisiner? Hva har hjulpet, og hva har ikke hjulpet?

Kategorien Juridisk informasjon er lett tilgjengelig som lenker. Som vaktlege ville jeg i tillegg $\emptyset$ nsket meg en mer konkret oppsummering med praktiske råd og veiledning til journalføring. Et godt eksempel er det som nevnes under Tilsyn ved bruk av mekaniske tvangsmidler.

Appendiks-delen inneholder oppsett for primærjournal, innkomstnotat for andre opphold og senere somatisk og nevrologisk undersøkelse, ordforklaringer og nyttige adresser. Dette er praktisk og informativt. Det siste hovedtemaet, Søkefunksjon, er litt primitivt.

Dette en enkel app med grei navigasjon, den er lett å forstå, og informasjonen er kvalitetssikret gjennom sporbare kilder. Jeg har et sterkt ønske om at dette prosjektet videreutvikles. Her er det muligheter for å legge inn utvidet informasjon, bokmerkefunksjon, linker, videoer osv. Noen må gi penger til videreutvikling og design!

Veileder i akuttpsykiatri representerer en helt riktig tankegang for klinikere kvalitetssikret informasjon der du er. Det er tiltrengt.

Publisert: 5. mars 2018. Tidsskr Nor Legeforen. DOI: 10.4045/tidsskr.17.1004

(C) Tidsskrift for Den norske legeforening 2020. Lastet ned fra tidsskriftet.no 